\title{
The Leadership of the CPC and the Great Rejuvenation of the Chinese Nation
}

\author{
Lingli ZHU (Corresponding author) \\ School of Marxism, Southeast Jiaotong University, Chengdu, Sichuan, China
}

Received: October 13, 2021 Accepted: October 25, $2021 \quad$ Published: November 2, 2021

doi: $10.5296 /$ jsss.v8i2.19136

URL: https://doi.org/10.5296/jsss.v8i2.19136

\begin{abstract}
To realize the great rejuvenation of the Chinese nation, we must adhere to the leadership of the CPC. The nature and purpose of the Party determine that only by adhering to the leadership of the CPC can we organize and mobilize the people, create a stable environment, and finally achieve the glorious goal of people's happiness. Guided by Marxism, the CPC constantly promotes theoretical innovation, which can gather the ideological consensus of realizing national rejuvenation. The road of socialism with Chinese characteristics led by the $\mathrm{CPC}$ is the only way to realize the great rejuvenation of the Chinese nation.
\end{abstract}

Keywords: the CPC, the leadership of the CPC, the Chinese nation, great rejuvenation

\section{Introduction}

From the law of the development of human society, the rise of any nation can not be separated from the leadership of advanced social forces, the guidance of advanced theory and the choice of the right way. Under the leadership of the CPC, the Chinese nation ushered in a great leap from standing up, getting rich to strengthening, and ushered in a bright prospect of the great rejuvenation of the Chinese nation. Adhering to the leadership of the CCP is the key factor related to the overall strategic situation from the strategic overall situation of realizing the great rejuvenation of the Chinese nation. To investigate the position and role of the Party's leadership in the great rejuvenation of the Chinese nation from the aspects of the initial mission, theoretical guidance and road opening of the Communist Party of China is the proper meaning in exploring the overall situation of the great rejuvenation strategy of the Chinese nation.

\section{The Party's Overall Leadership Is the Fundamental Guarantee for the Great Rejuvenation of the Chinese Nation}

The CPC has been the vanguard of the Chinese working class and the Chinese people and the Chinese nation since its founding. The purpose of the CPC is to serve the people 
wholeheartedly. The initial mission of the Chinese Communists is to seek happiness for the Chinese people and rejuvenation for the Chinese nation. The nature, purpose and initial mission of the Party ensure that the Party can do everything for the people and rely on them. By the support and trust of the $b$ the Chinese people, can unite the great rejuvenation of the Chinese nation.

\subsection{Only by Adhering to the Party's Leadership Can We Achieve the Good Goal of People's Happiness}

The scientific connotation and ultimate goal of the great rejuvenation of the Chinese nation are national prosperity, national rejuvenation and people's happiness. Only by adhering to the leadership of the Party can we achieve this goal. The CPC upholds the principle of putting people first and its a remarkable symbol of the difference between Marxist political parties and other political parties. Mao Zedong pointed out on 7th CPC National Congress" The CPC is a political party for the benefit of the nation and the people." "Serving the people wholeheartedly and maintain close ties with the people; do everything for the interests of the people, not for the interests of individuals or small groups; our starting points are both responsible to the people and the leading organs of the Party; these are our starting points." Over the past 100 years, the CPC upholds the principle of putting people first and serve the people wholeheartedly for the independence and revitalization of the Chinese nation .

The unswerving goal of the Communist Party of China is to Leading the people to create a happy life. The peasants were brutally exploited by the landlord class in modern China, the most important thing is solve the land problem. The CPC led the agrarian revolution which made the long-term oppressed peasants truly realize the emancipation. After the founding of New China, the Communist Party of China led the people to vigorously develop the productive forces, constantly enhance their comprehensive national strength, and the People's lives continue to improve by developing the productive forces and enhancing integrated national capacity. Reform and opening up is a new great revolution led by the CPC under the new era and the key to determining China's destiny. Since the reform and opening up, China has maintained a high rate of economic growth, steadily solved the problem of food and clothing for more than one billion people, and at the same time continuously met the needs of the people in the areas of democracy, rule of law, fairness, justice, security, environment, and so on, and achieved a well-off society in general.

Since the 18th National Congress of the CPC, the CPC in order to satisfy the expectations of the overwhelming majority of the people for a better life, embodied the idea of people-centered development in all aspects of economic and social development, and made great efforts to achieve "what the masses care about, what they expect, what the reform must grasp and what to advance". We focus on ensuring and improving the people's livelihood, develop various social undertakings, increase the adjustment of income distribution, guarantee the people's equal participation and equal right to development, make the fruits of reform and development more and more equitable and benefit the benefit of all the people. In particular, winning the battle of poverty alleviation has created a miracle in the history of world poverty reduction. From 2012 to 2020, after eight years, nearly 100 million rural poor 
people have been lifted out of poverty, and 832 poor counties get out of poverty that achieving the poverty reduction goals of the United Nations 2030 sustainable development agenda 10 years ahead of schedule. Without the strong leadership of the CPC, it is impossible to create such a miracle.

The CPC serves the people wholeheartedly, to uphold, safeguard and develop the fundamental interests of the overwhelming majority of the people, what the people advocate, what the people approve and accept must be the sole measurement of all of our work. So that the Party has always had an inexhaustible source of strength and become the core of strong leadership to realize the great rejuvenation of the Chinese nation.

\subsection{Only by Adhering to the CPC's Leadership Can We Bring Together Chinese Strength to Realize the Great Rejuvenation of the Chinese Nation}

People are the creators of history. They are the real heroes, and the decisive force for social change. Lenin pointed out that" Without the revolutionary actions of millions of enlightened masses and the surging heroism of the masses, vigorous socialism would not be created." To realize the great rejuvenation of the Chinese nation, we must extensively mobilize and organize the people to devote themselves to the great struggle to realize the great dream. The Communist Party of China has such strong organizational strength and cohesion.

Old China has been called a mass of sand in history. Mao Zedong noted in "On the Protracted War"," Japan dares to bully us, mainly because of the disorganized state of the Chinese people." As early as the march into Jing gangshan, Mao Zedong creatively put forward the organizational system of "branch building on the company ", so that the army has the backbone, ensures that the Party's correct ideas are carried out at the grass-roots level in a timely and in-depth manner, and inspires the fighting spirit of the broad masses of officers and soldiers. At the same time, it also helps party organizations to carry out mass work through cadres, publicize the masses, mobilize the masses, and organize the masses and the broad masses of soldiers to become one.During the war of resistance against Japanese aggression, The CPC actively advocated the establishment of the united front against Japanese aggression based on cooperation between the Kuomintang and the Communist Party, including all democratic parties, people's organizations and all patriotic classes and strata. At the call of the United Front, all ethnic groups, classes, parties, social organizations, patriots from all walks of life, compatriots from Hong Kong and Macao and overseas Chinese united as one and joined in this great struggle related to the survival of the nation. At the same time, the CPC insisted on mobilizing the people, relying on the people, carrying out independent guerrilla warfare behind the enemy lines, establishing anti-Japanese democratic base areas behind the enemy lines, and effectively mobilizing, organizing and strengthening anti-Japanese forces. During the War of Liberation, the CPC fully mobilized and organized the masses, relied on the strength of the people to overthrow the reactionary rule of the Kuomintang, and won the great victory of the new democratic revolution.

After the founding of New China, the CPC, as the ruling party, has more favorable conditions, more adequate resources and a more sound system and organizational system to mobilize and organize the masses to form a powerful force to promote social development and progress. 
Practice has proved that only by adhering to the leadership of the CPC can we truly respect the status of the people as subjects and ensure that the people are masters of their own affairs, Upholding and improving the system of people's congresses, the system of CPC-led multiparty cooperation and political consultation, the system of regional ethnic autonomy, the system of community-level self-governance. We will develop socialist consultative democracy, consolidate and develop the broadest patriotic united front, continuously expand the people's orderly political participation, and ensure the broad participation of the people in national and social governance. Only by this way can we gather the world's talents, attract and rally the outstanding talents within and outside the party, at home and abroad, to give full play to the enthusiasm, initiative and creativity of the broad masses of the people, and to rally the majestic power to realize the great dream.

National unity is both the lifeline of the people of all ethnic groups and the basic premise for realizing the great rejuvenation of the Chinese nation. Multi-ethnicity is a major feature of our country and a favorable factor for our development. Multi-ethnicity is a major feature of our country and a favorable factor for our development. General secretary Xi Jinping asserted," All nations need to work hard, hand in hand, shoulder to shoulder to realize the great rejuvenation of the Chinese nation." Only by adhering to the leadership of CPC can we fostering a strong sense of national identity and unite the majestic strength of the people of all nationalities. The CPC is the core force to realize and promote national unity. In all historical periods of revolution, construction and reform, the CPC has always placed national unity in an important position in the work of the whole party. The system of regional ethnic autonomy is one of the basic political systems of our country and an important guarantee for the realization of equality, unity and common prosperity of all nationalities.Since the Party's 18th National Congress, the Party Central Committee with Comrade Xi Jinping as the core has attached great importance to national work, focused on fostering a strong sense of national identity, innovated and promoted the development of national unity and progress, and made remarkable achievements. the Party's 18th National Congress writeten the fostering a strong sense of national identity into the constitution of the party. The Fourth Plenary Session of the 19th Central Committee of the CPC regards "adhering to the equality of all nationalities, building the sense of community of the Chinese nation, realizing common unity and struggle, and common prosperity and development" as the remarkable advantages of our national system and national governance system. Practice has proved that only under the leadership of the CPC can we consolidate and develop the socialist national relations of equality, unity, mutual assistance and harmony, and jointly realize the great rejuvenation of the Chinese nation.

\subsection{Adhere to the Leadership of the CPC to Create a Stable Environment for National Rejuvenation}

"Maintaining social stability is the top priority of governing the country. "Security and stability is the premise of development, without a harmonious and stable social environment, all reform and development can not be discussed. As General Secretary Xi Jinping said :"to achieve the great rejuvenation of the Chinese nation Chinese Dream, to ensure that the people live and work in peace and contentment, national security is the top priority ".The fifth 
plenary session of the 19th Central Committee of the CPC suggested that it is necessary to coordinate development and security, and bring them into the guiding ideology of economic and social development in the 14th Five-Year Plan period, so as to build a higher level of peaceful China.

National security is the basic requirement of people's happiness and well-being and an important cornerstone to bring peace and stability to the country. Many countries not only lose the opportunity of development, but also bring great disaster to the local people because of political instability and social unrest. Now the world is undergoing changes unseen in a century, Our country is faced with a complex and changeable security and development environment. All kinds of foreseeable and unpredictable risk factors are obviously increased, and the task of maintaining national security and social stability is even more arduous. Only by adhering to the strong leadership of the CPC can we properly handle social contradictions, maintain social stability, adhere to the holistic approach to national security and safeguard national security in all fields. Since the reform and opening up, China has achieved the miracle of rapid economic growth and sustained social stability, which fully embodies the remarkable advantages of the leadership of the CPC and the socialist system with Chinese characteristics.

The CPC has always made maintaining national security and social stability a top priority. In the early years of New China, the state launched a counter-revolutionary campaign against the remnants of the Kuomintang, which ensured the consolidation of the people's power and the stability of people's lives. In 1950, when the Korean War broke out, the U. S. troops, despite repeated warnings from the Chinese government, brazenly crossed the 38th line and burned the war to the border between China and North Korea.The US military aircraft bombed the northeast border area of China many times, causing serious losses to people's lives and property, and facing serious threats to our country's security. At this critical juncture, the CPC with extraordinary spirit and courage to make a historic decision to resist and aid Korea, protect the country's historic decision.The resist US aggressors and aid Korea war had safeguard the security of New China, safeguard the peaceful life of the Chinese people, and safeguard peace in Asia and the world.

After the establishment of the socialist system, the fundamental interests of the people, the overall interests-term interests of the people are consistent, but there are still contradictions.

Mao Zedong thoroughly studied the contradictions in the socialist society and formed a more systematic theory on the contradictions of different nature within the socialist society and how to deal with them. The contradictions in the socialist society can be divided into two categories: the enemy and the contradiction between the people, and the theme of the country's political life. The CPC's theory of socialist social contradictions and a series of principles for handling contradictions among the people provide a fundamental basis for correctly handling contradictions among the people and maintaining social stability.Since the reform and opening up, the CPC has insisted on organically combining scientific understanding and correct handling of contradictions among the people with practical solutions to the principal contradictions in the primary stage of socialism, vigorously 
developing productive forces, constantly meeting the material interests of the people, actively and effectively resolving and handling complex interests and contradictions among the people, focusing on solving people's livelihood problems, emphasizing that stability is the highest interest, properly handling contradictions and maintaining social stability. Since the 18th CPC National Congress, general secretary Xi Jinping called for strengthening the bottom line thinking, effectively preventing and managing national security risks, adhering to the overall concept of national security, responding to and resolving social security challenges, and ensuring national security and social stability.

Under the strong leadership of the CPC, our country has successfully withstsnd the test of political turmoil and the challenge of financial crisis, and effectively resolved the risks in the field of natural disasters and public health. The COVID-19 epidemic is the world's most serious infectious disease pandemic in a century. In the face of the sudden and serious epidemic situation, the CPC Central Committee has taken over the overall situation, made decisive decisions, insisted on putting the safety of people's lives and physical health first, implemented centralized and unified leadership at the first time, and organized the party, government, military and civilian studies, and the battle between the east, west, north and south. General Secretary Xi Jinping said affectionately," in the face of protecting people's lives, we must do everything at all costs, and we can do it at all costs, because the fundamental purpose of the Communist Party of China is to serve the people wholeheartedly. Our country is a socialist country in which the people are masters. We decisively closed the passage from Han to Hubei, the implementation of unprecedented strict control. This decision requires great political courage and bold historical commitment. In order to protect people's lives, we can do anything!"

Without a consolidated national defense and a strong army, peaceful development will not be guaranteed. In the national security system, military security plays a vital pillar and safeguard role. The reason why the people's army can effectively guarantee the national sovereignty, security and development interests lies in adhering to the Party's command of guns and the absolute leadership of the CPC over the army. The great rejuvenation of the Chinese nation will inevitably face all kinds of major challenges, major risks, major resistance and major contradictions. The connotation and extension of our security in the new era, the field of time and space, internal and external factors have undergone profound changes, and the comprehensive, global and extroverted characteristics of security needs are more prominent. There is an urgent need to build and consolidate national defense and a strong army. Only under the leadership of the CPC, can we build a people's army that listens to the Party's command, can win a battle and has a fine style of work, so as to provide a strong guarantee for the realization of the great rejuvenation of the Chinese nation.

\section{The Party's Guiding Ideology Is the Theoretical Guide for Realizing the Great Rejuvenation of the Chinese Nation}

Thought is the forerunner of action, theory is the guide of practice. Every historic leap in human society is based on theoretical cognition, theoretical summary and theoretical innovation of new practice. The CPC combines Marxism with Chinese reality, forms the 
theoretical achievement of Marxism in China, which is the action guide to realize the great rejuvenation of the Chinese nation.

\subsection{To Realize the Great Rejuvenation of the Chinese Nation, We Must Adhere to the Guidance of Marxist Scientific Theory}

Only by consciously adhering to and applying Marxist stand, viewpoint and method can great dreams be realized through great struggle. Firstly, the principle of world material unity is the cornerstone of Marxist philosophy. Only by following this view can we persist in formulating policies and promoting work from objective reality. Secondly, Marxism believes that contradictions are universal, the essence of the relationship between things and the fundamental driving force of the development of things. Only adhere to problem-oriented, face-to-face contradictions, good at resolving contradictions can promote career development. Thirdly, Marxism reveals the characteristics of universal connection and eternal development of the material world, and requires people to make full use of dialectical methods to observe and deal with problems in the process of understanding and transforming the world, and to overcome extreme and one-sidedness. Fourthly, Marxism believes that material production is the basis of social life, and productivity is the most active and revolutionary element to promote social progress. Relations of production can also be reversed to productive forces, superstructure can also be reversed to the economic base. To follow this basic view, we must concentrate on construction, and we must comprehensively deepen reform in all fields around the first priority of development, and further liberate and enhance social vitality.

In May 2018 , General Secretary Xi Jinping delivered an important speech at the ceremony commemorating the bicentenary of the birth of Marx, It has profoundly explained the scientific connotation and great significance of Marxism, and clearly put forward the specific requirements for studying and practicing Marxism, upholding and developing socialism with Chinese characteristics in the new era, including studying and practicing Marxist ideas on the law of human social development, upholding the people's stand, productive forces and relations of production, people's democracy, cultural construction, social construction, relationship between man and nature, world history, Marxist party building, etc. General secretary Xi Jinping pointed out :" Practice has proved that the fate of Marxism has long been closely linked with the fate of the Communist Party of China, the fate of the Chinese people, the fate of the Chinese nation, its scientific nature and truth have been fully tested in China, its people and practicality have been fully implemented in China, its openness and the times have been fully demonstrated in China!"

\subsection{Realizing the Rejuvenation of the Chinese Nation Requires the Promotion of Sinicization of Marxism}

Marxism is a powerful ideological weapon for us to understand the world, grasp the law, pursue truth and transform the world, but it is not a ready-made answer to solve specific problems, and it can not be dogmaticized. Engels profoundly pointed out :" Marx's whole world outlook is not doctrine, but method. It provides not ready-made dogma but the starting point for further research and the methods used for such research ." Engels also pointed out that our theory, "is a product of history, it has completely different forms in different times, at 
the same time has completely different content." The reason why Marxism can profoundly change China is that the Communist Party of China constantly promotes the Sinicization of Marxism, forms the theoretical achievements of Marxism in China, and realizes the Party's guiding ideology to keep pace with the times.

In the new journey of realizing the great rejuvenation of the Chinese nation, the key to promoting the Sinicization of Marxism is to combine Marxism with China's reality.

First, we must adhere to Marxism and not lose it. Although our time has undergone great and profound changes compared with that of Marx, from the perspective of 500 years of world socialism, we are still in the historical era indicated by Marxism. The general principles expounded by Marxism are still completely correct. We must always adhere to and apply Marxist positions, viewpoints and methods to observe society and guide practice. We must not doubt the basic principles because of changes in conditions, we must not waver in the basic principles because of new problems, we must not lose our determination to the basic principles because of new trends of thought, we must maintain theoretical sobriety and strengthen political stability.

Second, to the national conditions and the characteristics of the times have an accurate grasp. Marxism is not dogma, only by closely combining the basic principles of Marxism with the specific reality of our country, historical and cultural traditions, and the requirements of the times, constantly exploring and summing up in practice, forming a new scientific theory, can we really guide practice. Mao Zedong once solemnly put forward to the whole party :" make Marxism concrete in China, make it in every performance with the necessary Chinese characteristics, that is, according to the characteristics of China to apply it, become the whole party needs to understand and urgent to solve the problem ." Following this ideological principle, the $\mathrm{CPC}$, in the great process of leading revolution, construction and reform, has continuously promoted the popularization and epochalization of Marxism, and has successively formed Mao Zedong's thought, Deng Xiaoping's theory, the important thought of "three represents ", the scientific outlook on development view, and Xi Jinping's socialist thought with Chinese characteristics in the new era. These scientific theories are great theoretical innovations based on the accurate grasp of the national conditions and the accurate cognition of the characteristics of the times under the guidance of Marxism. It is these scientific theories that have led to great changes in China, and the Chinese nation has ushered in a great leap from standing up, getting rich to being strong.

Third, pay attention to the theory of strengthening the party. The combination of Marxism and Chinese reality can not be spontaneous, it needs hard exploration and theoretical creation, and the Chinese Communists need profound theoretical foundation, persistent historical responsibility, great courage to advance in spite of difficulties and excellent thinking that is good at pioneering and innovating. In 1938 mao zedong pointed out :" if our party had learned marxist-leninist comrades in a systematic way, not piecemeal, practical, rather than empty, way, it would have greatly enhanced the fighting power of our party. " One of the important reasons why the CPC can continuously promote the Sinicization of Marxism and realize theoretical innovation is that it always attaches importance to party building, 
strengthen the Party in theory, and persist in arming the mind with the latest theoretical achievements of Sinicization of Marxism, so that the whole Party can always maintain a unified mind, firm will, strong combat effectiveness and vigorous creativity.

\subsection{To Realize the Great Rejuvenation of the Chinese Nation, We Need to Build a Common Ideological Foundation}

General secretary Xi Jinping pointed out:" a country, a nation, to move forward with one heart and one mind, we must have common ideals and beliefs to support." Ideals and beliefs are the spiritual pillar and the source of strength. Looking back on the century-old journey of the Communist Party of China to unite and lead the people to struggle, the reason why it can overcome all difficulties and obstacles and create a human miracle is because of the encouragement and cohesion of ideals and beliefs. Marxism has laid the theoretical foundation of the Communists' firm ideals and beliefs and is the spiritual pillar for the Communists to withstand any test. Stalin famously said :" Communists are people with a certain special character, we are made of special materials . Communists, as part of social groups, have the same joys and sorrows as ordinary people, but the difference between Communists and ordinary people is that they are a special social group made of "special materials ". This special material is the firm Marxist belief and the lofty ideal of realizing communism. The ideals and beliefs of the Communists are embodied in the way of behavior, that is, to always adhere to the people's stand and serve the people wholeheartedly. With such ideals and beliefs, in the years of the revolutionary war, the Communists will be able to live and die for the cause of the Party and the people, and in the period of peace-building, the Communists will be able to bear hardships before and after, shoulder heavy burdens in front of urgent, dangerous and heavy tasks, and stand various tests in real life. As General secretary Xi Jinping stressed :" With firm ideals and beliefs, you will stand high, your horizons will be wide, your mind will be open, you will be able to adhere to the correct political direction, you will not be proud and impatient in victory and prosperity, you will not be depressed in difficulties and adversity, you will withstand all kinds of risks and difficulties, resist the erosion of decadent ideas, and you will always preserve the political character of the Communists ." In the critical period of realizing the great rejuvenation of the Chinese nation, the task of reform, development and stability is unprecedented, and the number of risks and challenges is unprecedented. The more difficult the task, the more complex the situation, the more need to strengthen ideals and beliefs, the more need for spiritual support.

When a people have ideals, their country will have strength, and their nation will have a bright future. If a country or a nation has a common ideological basis, it can unite as one to achieve a common cause and achieve a common goal, otherwise it will be scattered, accomplish nothing, and even social unrest and ethnic division. The great cause of revolution, construction and reform led by the people of the Communist Party of China is because of the common ideological basis of Marxism, which can unite the will and strength of the people of all ethnic groups throughout the country, overcome all kinds of difficulties and obstacles on the way forward, and constantly move from victory to victory. Looking at the world, the turbulence and division of some countries often begin with the vacillation of ideals and beliefs and the confusion of ideas. The collapse of the Soviet Union, the upheaval in Eastern 
Europe, and the "color revolution" in some countries in recent years are a warning. Building a common ideological foundation requires ideological work. General secretary Xi Jinping pointed out:" ideological work is an extremely important work of the Party, is for the national heart, for the national soul of the work." Decision of the central committee of the communist party of China on major issues concerning upholding and Improving socialism with Chinese characteristics and modernizing the state governance system and capacity deliberated and adopted a the fourth plenary session of the 19th central committee of the CPC, put forward the fundamental system of adhering to the guiding position of Marxism in the ideological field. This is the first time that the CPC has clearly put forward the guiding position of Marxism in the ideological field as a fundamental system, which reflects the Party's understanding of the law of socialist construction into a new realm. Only by adhering to this system can we adhere to the correct road of development, realize the long-term stability of the country, build the common ideological foundation of all the people, and provide a strong ideological guarantee and strong spiritual power for the realization of the great rejuvenation of the Chinese nation.

The core values embody the cultural ideal and spiritual height of a country and a nation, are the spiritual bond on which a nation depends, and are the common ideological and moral foundation of a country. The core socialist values embody the contemporary Chinese spirit and condense the common value pursuit of all the people. Only by taking the cultivation and practice of socialist core values as the basic project of gathering spirit and strengthening the foundation and strengthening the foundation can we build the ideological and moral foundation for realizing the great rejuvenation of the Chinese nation. In the final analysis, the construction of core values is the ideological construction of human beings, that is, to create socialist builders with correct world outlook, outlook on life and values. The correct world outlook we emphasize, of course, refers to the Marxist world outlook. Only by adhering to Marxism, firmly establishing the lofty ideal of communism and the common ideal of socialism with Chinese characteristics, and cultivating and practicing the socialist core values, can we build the Chinese spirit and Chinese value and provide spiritual guidance for realizing the great rejuvenation of the Chinese nation.

\section{The Socialist Road with Chinese Characteristics Initiated by the CPC Is the Only Way to Realize the Great Rejuvenation of the Chinese Nation}

The road determines fate. The CPC relying on the masses of the people and combining the basic principles of Marxism with China's reality and characteristics of the times, has taken its own path independently and independently. After many hardships and various costs, we have won the great victory of revolution, construction and reform, created and developed socialism with Chinese characteristics, and fundamentally changed the future and destiny of the Chinese people and the Chinese nation. Practice has proved that the path of socialism with Chinese characteristics is the only way to create a better life for the people and the only way to realize the great rejuvenation of the Chinese nation. Theory is the guide of action. As mentioned above, the theoretical system of socialism with Chinese characteristics is the scientific theory that guides the Party and the people to realize the great rejuvenation of the Chinese nation. Adhere to the correct road must have institutional protection. The socialist 
system with Chinese characteristics formed in practice and exploration is the fundamental political system of the people's Congress system, the system of CPC-led multi-party cooperation and political consultation, the system of regional ethnic autonomy and the system of community-level self-governance, as well as the relevant specific systems. The enrichment and perfection of the system make the road of socialism with Chinese characteristics wider. Socialist culture with Chinese characteristics is a powerful spiritual motive force to encourage the whole party and the people of all ethnic groups to advance courageously. Only by strengthening the road confidence, theory confidence, system confidence and cultural confidence of socialism with Chinese characteristics can we avoid the old road of closure and ossification and the evil road of changing flags and changing flags, and adhere to the road of socialism with Chinese characteristics to realize the great rejuvenation of the Chinese nation. The most essential characteristic of socialism with Chinese characteristics is the leadership of the CPC, and the greatest advantage of the socialist system with Chinese characteristics is the leadership of the CPC. Adhering to the road of socialism with Chinese characteristics requires the Party to make scientific judgment and strategic plan in grasping the development opportunities, promoting the modernization of the national governance system and governance ability, and so on.

\subsection{Scientific Judgment of the Situation Is an Important Prerequisite}

Scientific study of the situation has always been the premise of making correct decisions and the basis for promoting the implementation of decisions. Through a comprehensive understanding of the international situation, accurately grasp the domestic situation. When the situation is favorable, we should see the latent crises and adverse factors, always keep a clear mind, strengthen the sense of suffering, prepare ahead of time, and prepare for the adverse situation. When the situation is unfavorable, we should be good at finding the turning point, firmly reverse the confidence of the unfavorable situation, turn the challenge into the opportunity, and turn the unfavorable factors into the favorable factors. One hundred years of historical experience has shown that the Communist Party of China can scientifically judge the situation, accurately understand the historical position from the development coordinates of the world and the times, formulate correct principles and policies, and lead the people of the whole country to work together to create a new situation at a new starting point.

General Secretary Xi Jinping has repeatedly stressed that leading cadres should keep in mind the great changes in the world and the overall situation of the great rejuvenation strategy of the Chinese nation. This is the scientific orientation and accurate grasp of the world situation and the historical position of our country. Standing at the historical intersection of "two century years ", the Fifth Plenary session of the 19th CPC Central Committee made systematic plans and strategic arrangements for economic and social development during the 14th Five-Year Plan period, and clearly put forward the current and future periods. China is still in an important strategic opportunity period, but opportunities and challenges have changed. This important judgment provides a fundamental basis for us to correctly understand the situation and task of national rejuvenation and effectively deal with risk challenges. In order to truly keep in mind the two overall situation, we must deeply understand the changes of the domestic and foreign environment, opportunities and 
challenges faced by our country in the stage of development.

Today, the world is faced with a century of great changes ," peace and development "is still the theme of the times, while the international environment is becoming more and more complex, instability, uncertainty significantly enhanced. On the one hand, the world of human communication is more in-depth and extensive than ever before, the world is multipolar, economic globalization, social informatization, cultural diversity continue to advance in depth, peace, development, cooperation, win-win is an irresistible historical trend. On the other hand, the number, scale and degree of global problems facing mankind are unprecedented, and governance deficit, trust deficit, peace deficit and development deficit have become the common challenges of the world. In addition, the COVID-19 epidemic has exacerbated the world's century-old changes, international political, economic, cultural, security and other patterns are undergoing profound adjustments. In the coming period, my country will also face more difficult external environmental challenges. However, China's economic stability to good, long-term good fundamentals have not changed, China's development potential, toughness, strong vitality, large swing space, policy tools have not changed the basic characteristics, China's development has not changed in many aspects of the advantages and conditions. On the way forward, scientific analysis of the situation, grasping the general trend of development, adhering to the general tone of the work of seeking progress in a steady manner, adhering to the new concept of development, coordinating development and security, speeding up the formation of a new pattern of development, and achieving high-quality, efficient, more equitable and more sustainable development will surely overcome difficulties and obstacles and realize the great rejuvenation of the Chinese nation.

\subsection{Advance the Modernization of China's System and Capacity for Governance Is an Important Guarantee}

The national system is the premise and guarantee of national governance, and all activities of national governance are carried out in accordance with the national system. The state system of our country is the system of governing the country under the leadership of the Party, and it is a set of closely linked and coordinated systems, including the leadership system of the Party, the fundamental political system of the country, the basic political system, the basic economic system, and the important system and legal system of the country in all aspects, such as the politics, economy, culture, ecological civilization, military affairs, etc. This system prescribes the nature, mutual relationship and operation rules of the development of all aspects of our country's undertakings, is the fundamental basis of national governance, has strong vitality and remarkable advantages, and is the fundamental guarantee of the development and progress of contemporary China.

Adhering to and perfecting the socialist system with Chinese characteristics and promoting the modernization of the national governance system and governance are an organic unified system engineering. General Secretary Xi Jinping stressed :" To promote the modernization of the national governance system and governance capacity is to adapt to the changes of the times, not only to reform the institutional mechanisms, laws and regulations that do not meet 
the requirements of the development of practice, but also to constantly build new institutional mechanisms, laws and regulations, make all aspects of the system more scientific and perfect, and realize the institutionalization, standardization and procedure of the governance of the party, state and society." At present, China's national governance is faced with some new situations and problems. There are still many areas in need of improvement in the governance system and governance capacity. At the same time, the national system is not perfect, the legal system is not perfect, the degree of social participation and mass autonomy is not high, and the level of institutionalization, standardization and procedure of governance needs to be improved. To prevent and resolve this series of major risks and effectively deal with the challenges from all aspects, we must break down the barriers of interest solidification, remove the institutional and institutional obstacles that hinder the development of social productive forces, and adapt the superstructure to the economic base.

Advancing the modernization of China's system and capacity for governance is the only way to put the socialist system with Chinese characteristics into practice and transform the advantages of the socialist system with Chinese characteristics into the efficiency of national governance. To complete this important strategic task, we must plan scientifically, organize meticulously and advance as a whole under the unified leadership of the Party Central Committee. First of all, from the status point of view, the CPC is the highest political leading force in our country and always insists on serving the people wholeheartedly. It is under the leadership of the Party that the socialist system with Chinese characteristics embodies and expresses the people's character of the system. It has fundamentally solved the problem of "for whom and who to rely on" in the socialist system with Chinese characteristics, and has been supported by the overwhelming majority of the Chinese people and condensed the strength of all the Chinese people. Secondly, from the point of view of the efficiency of national governance, the CPC is the backbone and pillar of the building of socialism with Chinese characteristics, and the advantage of the socialist system with Chinese characteristics is transformed into the efficiency of governance. This is the fundamental guarantee of institutional advantage. Secondly, from the point of view of the efficiency of national governance, the CPC is the backbone and pillar of the building of socialism with Chinese characteristics, and the advantage of the socialist system with Chinese characteristics is transformed into the efficiency of governance. This is the fundamental guarantee of institutional advantage.

\subsection{Innovation Is the Soul of National Progress}

The road of socialism with Chinese characteristics is the crystallization of the pioneering and innovation of the leading people of the Communist Party of China. Continuing to advance along this road still needs continuous reform and innovation in order to radiate strong vitality and vitality of innovation. Innovation is the soul of national progress, the motive force of national development, and the source of civilization. Innovation occupies the core position in the overall situation of socialist modernization construction in our country, which is particularly important and important for building a socialist modern country in an all-round way on the basis of building a well-off society in an all-round way. 
The Fifth Plenary Session of the 19th CPC Central Committee put forward :" Adhere to the core position of innovation in the overall situation of China's modernization drive, take science and technology self-reliance and self-improvement as the support of the national development strategy, face the world's scientific and technological frontier, main battlefield of the economy, face the major needs of the country, face the life and health of the people, thoroughly implement the strategy of rejuvenating the country through science and education, the strategy of strengthening the country with talents, and the strategy of innovation-driven development, perfect the national innovation system, and speed up the construction of a powerful country in science and technology . This is the first time the CPC's previous planning recommendations explicitly mentioned innovation "core position ". Innovation is the first driving force to lead development which strengthen the development momentum and change the development model. Whether it is to strengthen the motive force of development, occupy the commanding point of development, or change from extensive development mode to new development mode, the core content and the most important symbol are innovation drive. The essence of high quality development stage and high speed growth stage is different from pursuing speed to pursuing quality, from scale expansion to structural optimization, from factor drive to innovation drive.

To grasp innovation is to grasp development, and to seek innovation is to seek the future. In today's world, who can take the initiative to lead innovation can master the initiative to lead innovation. Although our country has become the second largest economy in the world, the innovation ability is still not strong, and the situation that the key core technology is controlled by others has not changed fundamentally. From the experience of historical development, the core technology can't be bought, but also can't be exchanged, in the introduction of high-tech can't have any illusions.

Under this background, we must find an innovative way suitable for national conditions and master more core technologies in order to grasp the initiative of competition and development. General Secretary Xi Jinping pointed out:" If China wants to be strong and rejuvenate, it must vigorously develop science and technology and strive to become the world's main scientific center and innovation highland. We are closer to the goal of the great rejuvenation of the Chinese nation than at any time in history, and we need to build a scientific and technological power more than at any time in history !" In the face of a series of new opportunities and challenges brought about by the profound changes in the environment at home and abroad, the CPC Central Committee has made a major strategic choice to speed up the establishment of a "dual circulation" development pattern in which domestic economic cycle plays a leading role while international economic cycle remains its extension and supplement.

\section{Conclusion}

Adhering to reform and innovation, remove old things and create new ones, our party has created and developed the socialist road with Chinese characteristics. History and reality have proved that the road of socialism with Chinese characteristics is the only way for the Chinese nation to realize national prosperity, national rejuvenation and people's happiness. The Communist Party of China is determined to be a great cause of the Chinese nation. Looking 
forward to the future, the Communist Party of China will lead the Chinese people to build our country into a prosperous, democratic, civilized, harmonious and beautiful socialist modern power on the road of socialism with Chinese characteristics, and realize the great rejuvenation of the Chinese nation.

\section{References}

(2014). Selection of important documents since the 18th National Congress (first volume ), Beijing: Central Literature Publishing House.

. (2019). Outline of the Study on Socialism with Chinese Characteristics in the New Era of Xi Jinping, Beijing: Study Press, People's Publishing House.

(2020). CPCCC's proposals for the formulation of the 14th Five-Year Plan (2021-2025)

for National Economic and Social Development and the Long-Range Objectives Through the Year 2035. People's Daily, 1, 11-04.

Lenin. (2017). Complete Works of Lenin, Volume XVII. Beijing: People's Publishing House.

Mao, Z. D. (1991). Selections of Mao zedong, Volume II. Beijing: People’s Publishing House.

Mao, Z. D. (1991). Selections of Mao zedong, Volume III. Beijing: People's Publishing House.

Marx \& Engels (1995).Selections of Marx and Engels, Volume IV. Beijing: People's Publishing House.

Stalin. (1995). Selections of Stalin ( first volume ). Beijing: People's Publishing House.

Wang, B. L. (2019). Promoting the Transformation of the Advantage of the Socialist Social System with Chinese Characteristics into the Efficiency of National Governance. China Party and Government Cadres Forum, 10, 23-26.

Xi, J. P. (2016). Important directives on the occasion of the first National Security Education Day for All. People 's Daily ,1, $04-15$.

Xi, J. P. (2017). Xi Jinping the governance of China, Volume II. Beijing: Foreign Language Publishing House.

Xi, J. P. (2018). Speech at the National Recognition Conference to mark the 200th anniversary of Marx's birth. Beijing: People's Publishing House.

Xi, J. P. (2018). Xi Jinping the governance of China, Volume I, Beijing: Foreign Language Publishing House.

Xi, J. P. (2020). Speech at the National Recognition Conference to commend role models in China's fight against the COVID-19 epidemic , People 's Daily ,1, 09-09.

Xi, J. P. (2020). Xi Jinping the governance of China, Volume III, Beijing: Foreign Language Publishing House. 
Xi, J. P. (2020).The governance of China, III. Beijing: Foreign Language Publishing House.

\section{Copyright Disclaimer}

Copyright for this article is retained by the author(s), with first publication rights granted to the journal.

This is an open-access article distributed under the terms and conditions of the Creative Commons Attribution license (http://creativecommons.org/licenses/by/4.0/). 